Proceeding of the $2^{\text {nd }}$ International Conference on Agriculture, Food Security and Safety, Vol. 2, 2021, pp. 44-53 Copyright $\odot 2021$ iConferences

ISSN 2682-7158

DOI: https://doi.org/10.32789/agrofood.2021.1004

\title{
Occupational Health Hazards of Women in Agriculture - A Study on Bargarh District of Odisha
}

\author{
Sahu $\mathrm{S}^{1}$ and Lenka $\mathrm{C}^{2}$
}

${ }^{1}$ Ph.D. Scholar P.G. Department of Home Science, Sambalpur University, India, suravi.smart@gmail.com

${ }^{2}$ Reader \& Head in Home Science, P.G. Department of Home Science, Sambalpur University, India,

chandrashree66@gmail.com, lenkachandrashree@yahoo.com 


\title{
OCCUPATIONAL HEALTH HAZARDS OF WOMEN IN AGRICULTURE-A STUDY ON BARGARH DISTRICT OF ODISHA
}

\begin{abstract}
The woman is the backbone of the agricultural workforce but worldwide, her hard work has mostly been unpaid. The objective of the study was to find the common occupational health hazards in women agricultural workers and their effects and to find out the protective measures used by agricultural workers for the prevention of occupational health hazards. The present study was based on 110 samples of three villages of Bhatli Block in Bargarh District in the period of 20182019. The results revealed that physical hazards such as body pain $(86.36 \%)$ and fatigues $(83.63 \%)$ were most common in all agricultural activities. The majority of respondents $(77.24 \%)$ had mechanical hazards, i.e. injury occur due to farm tools and machinery. Chemical hazards like skin problems affected $39.09 \%$ of workers, and environmental hazards such as air-borne allergies $(32.72 \%)$, poisonous organism bites $(21.81 \%)$ were found common among the respondents, and no association was found between their socio-economic levels in the relevance of occupational health hazard. The agricultural workers were usually careless towards the prevention of occupational hazards.
\end{abstract}

Keywords: Women in agriculture, socio-economic class, occupational hazards

\section{Introduction}

Agriculture is considered one of the oldest occupations, perhaps as old as human civilization. Agriculture is the basic strength of the Indian economy, and the maximum population in India depends on agriculture only for their livelihood. The woman is the backbone of the agricultural workforce, but worldwide her hard work has mostly been unpaid. As farm women involve themselves both in household and farm activities, they are more prone to this. She does the most tedious and back-breaking tasks in agriculture, animal husbandry and homes. Presently they contribute one-third of the agricultural labour force and about 48 per cent of self-employed farmers. More than half of the world's food is grown by women. Women's work is both wide-ranging and multifaceted throughout the year, and they perform multiple tasks in the sphere of agriculture. They are exposed to both outdoor and indoor environments. It poses many health hazards to workers such as physical, mental, social, ergonomic hazards etc. (Nayak et al.).

From seed preparation to meal preparation, women's indigenous knowledge is significant and crucial in ensuring food security through sustainable agriculture. However, there is little recognition of their significant role and contribution to the socio-economic development of a nation. The entrenched social and religious norms that define women's role as secondary and subordinate keep women vulnerable and dependent and allow women's exploitation as agricultural workers and farmers. With this backdrop, the present study was carried out.

\section{Objective}

The objective of the present study is to find the common occupational health hazards of women in agriculture and their effects and to find out the protective measures used by agricultural workers for the prevention of occupational health hazards. 
Suravi, S. / Occupational health hazards of women in agriculture - a study on Bargarh district of Odisha

\section{Methodology}

Study area: The present study was conducted in three villages: Haladipali, Nuapali and Chadeigaon of Bhatli Block in Bargarh District.

Sampling Design: For the present study, a purposive sampling method was followed. 110 samples of women agricultural workers were selected as respondents.

Research Design: Keeping the objectives in mind, the exploratory cum descriptive research method was most suitable for the present survey.

Tools and techniques: Keeping the objectives of the study in mind, data was collected from women agricultural workers with the help of a predesigned pretested personal interview schedule and required tools.

\section{Result and Discussion}

Socio-economic profile of the respondents

Table 1: Distribution of respondents on the basis of socio-economic profile

\begin{tabular}{|c|c|c|c|}
\hline Sl. No. & Socio-economic profile & & \\
\hline 1.1. & Age & Number & Percentage \\
\hline a. & $20-30$ & 43 & 39.09 \\
\hline b. & $30-40$ & 32 & 29.09 \\
\hline c. & $40-50$ & 22 & 20 \\
\hline d. & $50 \& \mathrm{ABOVE}$ & 13 & 11.82 \\
\hline 1.2. & Caste & Number & Percentage \\
\hline a. & GENERAL & 8 & 7.27 \\
\hline b. & Other Backward Classes & 22 & 20 \\
\hline c. & Scheduled Tribes & 36 & 32.73 \\
\hline d. & Scheduled Castes & 44 & 40 \\
\hline 1.3 . & Education & Num ber & Percentage \\
\hline a. & Only Read and write & 28 & 25.45 \\
\hline b. & Primary & 35 & 31.82 \\
\hline c. & Middle & 17 & 15.45 \\
\hline d. & High School & 29 & 26.36 \\
\hline e. & More & 1 & 0.91 \\
\hline 1.4. & Monthly income & Number & Percentage \\
\hline
\end{tabular}


Suravi, S. / Occupational health hazards of women in agriculture - a study on Bargarh district of Odisha

\begin{tabular}{l|lll} 
a. & Less than 10000 & 58 & 52.73 \\
\hline b. & $10000-20000$ & 39 & 35.45 \\
c. & More than 20000 & 13 & 11.82 \\
\hline $\mathbf{1 . 5}$ & $\begin{array}{l}\text { Socio-economic class according to } \\
\text { Kuppuswamy Scale (Jan-2017) }\end{array}$ & Number & Percentage \\
a. & Upper Class & 0 & 0 \\
\hline b. & Upper Middle Class & 0 & 0 \\
c. & Lower Middle class & 31 & 28.18 \\
\hline d. & Upper Lower Class & 44 & 40 \\
e. & Lower Class & 35 & 31.81
\end{tabular}

Table 1 delineates results on the socio-economic profile of the respondents. Information on the age of mothers revealed that the majority of respondents (39.09\%) belonged to the age group 20-30 years, followed by $29.09 \%$ of respondents having age $30-40$ years. Only $20 \%, 11.82 \%$ of respondents belonged to the age group of 40-50 years and above 50 years respectively. Out of the total farm women, most of the respondents, i.e., $40 \%$, belonged to scheduled caste, $7.27 \%, 20 \%$, and $32.73 \%$ of respondents belonged to general, other backward class and scheduled tribe caste, respectively. The majority of the respondents had education up to the Primary School level, i.e., 31.82\%, whereas $15.45 \%$ of respondents were educated up to middle education, and $26.36 \%$ of respondents were educated up to high school education level. Only $0.91 \%$ of respondents had above high-level education, and the rest were found to be illiterates. The source of income is closely associated with the economic status of the family. It was found that the majority (52.73\%) of respondents had a monthly income of Rs. Less than 10000 followed by $35.45 \%$ of respondents had monthly family income Rs.10000-20000. Only $11.82 \%$ had a monthly income above Rs. 20000. Socio-economic status is a multi-dimensional index. As per the classification of socio-economic class, it was observed that the majority (40\%) of respondents belonged to the Upper Middle Class, and $31.81 \%$ of respondents belonged to the lower-class family. Only $28.18 \%$ of respondents belonged to the lower-middle class, whereas no respondents belonged to the upper and upper-middle class.

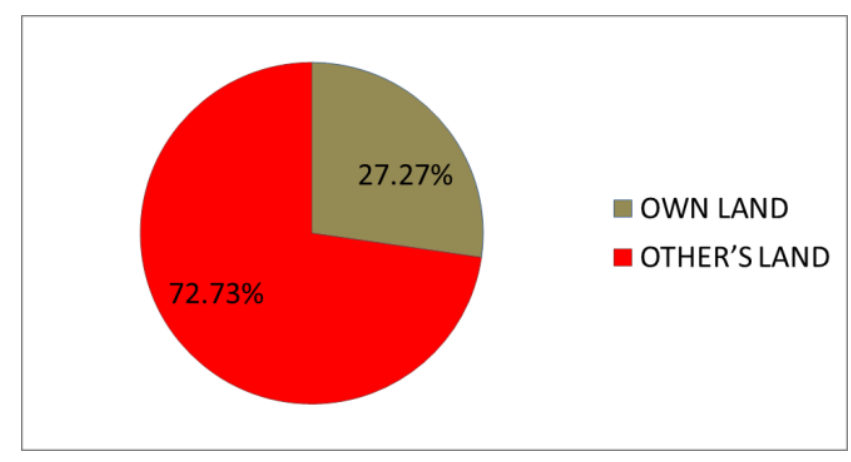

Figure 1 Distribution of respondents on the basis of working field

From figure 1, it was revealed that the majority $(72.73 \%)$ of the farm women were hired laborers, followed by their own land workers, i.e., 27.27\%. A similar finding was also observed by Pandey (2016). 
Suravi, S. / Occupational health hazards of women in agriculture - a study on Bargarh district of Odisha

\section{Type of Works}

Table 2: Distribution of respondents on the basis of type of work

\begin{tabular}{l|ll} 
TYPE OF WORK & NO. & \%AGE \\
\hline Fertilizer Carrying & 35 & 31.81 \\
Carrying Seeds & 32 & 29.09 \\
\hline Harvesting & 85 & 77.27 \\
Irrigation to field & 24 & 21.81 \\
\hline Cleaning Grains & 63 & 32.72 \\
Land Preparation & 43 & 39.09 \\
\hline Applying Fertilizer & 36 & 32.72 \\
Weeding & 95 & 86.36
\end{tabular}

Table 2 indicated that the majority of respondents $(86.36 \%)$ engaged in weeding on-farm, followed by $77.27 \%$ farm women who were involved in harvesting, whereas $31.81 \%, 29.09 \%, 21.815,32.72 \%$, $39.09 \%$ and $32.72 \%$ respondents engaged in fertilizer carrying, carrying seeds, irrigation to the field, cleaning grains, land preparation and applying fertilizer in the farm respectively.

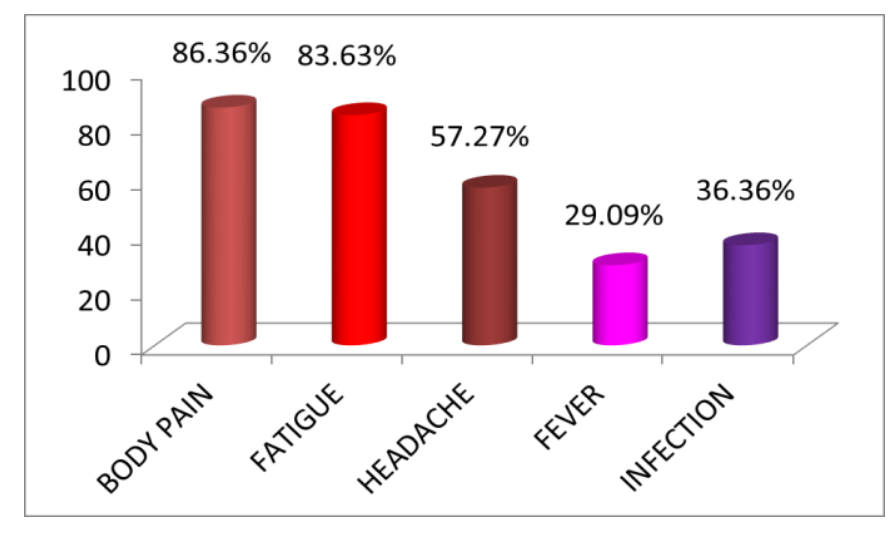

Figure 2 Distribution of respondents on the basis of physical hazards

Figure 2 revealed that in all the agricultural activities, physical hazards such as body pain $(86.36 \%)$ and fatigue $(83.63 \%)$ were most common, whereas $57.27 \%, 29.09 \%$ and $36.36 \%$ of respondents had headache, fever and infection, respectively. These were similar hazards faced by Meenakshi et al., 2020 .

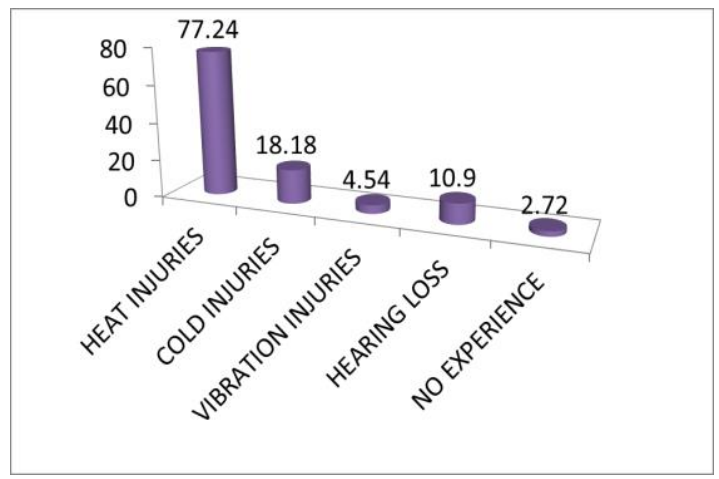

Figure 3 Distribution of respondents on the basis of mechanical hazards 

Odisha

The majority of respondents (77.24\%) had mechanical hazards, i.e. injury occurred due to farm tools and machinery. It was observed in figure 3. Cold injuries, vibration injuries and hearing loss experience by $18.18 \%, 4.54 \%$ and $10.9 \%$, respectively and only $2.72 \%$ of respondents had no experience of mechanical hazards.

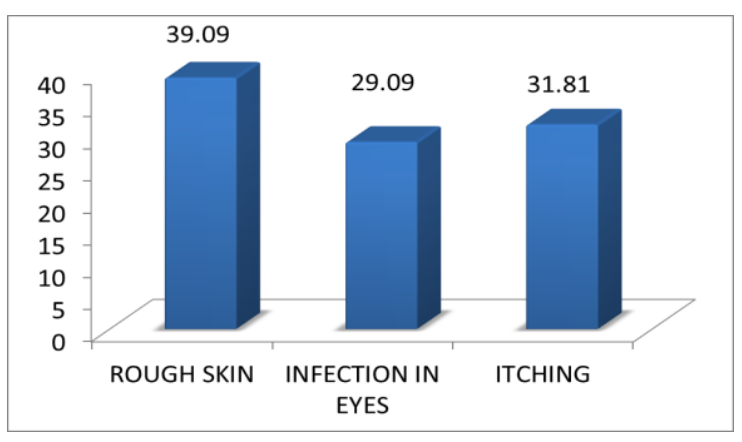

Figure 4 Distribution of respondents on the basis of chemical hazards

From figure 4, it was shown that chemical hazards like skin problems affected $39.09 \%$ of farmworkers, followed by $31.81 \%$ who felt itching of the body, and $19.09 \%$ of farmworkers suffered from infection of the eyes due to chemical hazards.



Figure 5 Distribution of respondents on the basis of environmental hazards

Figure 5 indicated that environmental hazards such as air-borne allergies (32.72\%), poisonous organism bites $(21.81 \%)$, and respiratory problem $(45.45 \%)$ were found common among the respondents.

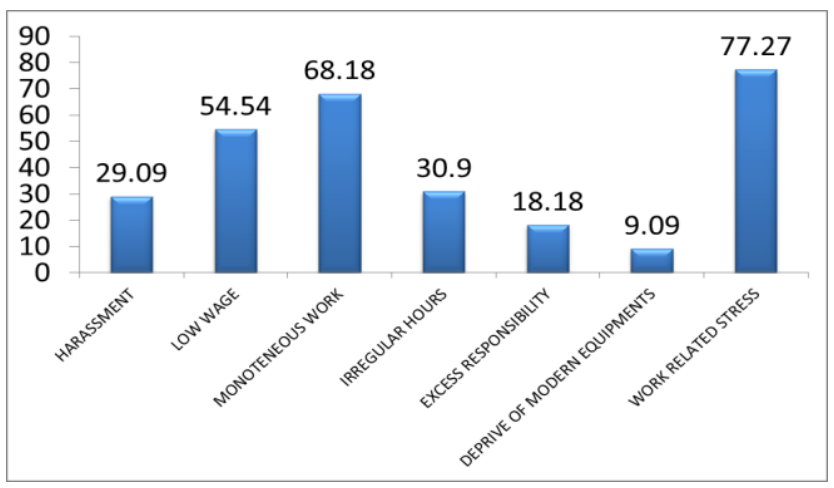

Figure 6 Distribution of respondents on the basis of psychological hazards 
Figure 6 indicated that most farm agricultural workers had work-related stress, i.e. $77.27 \%$, followed by $68.18 \%$ who had psychological hazards from monotonous work. Harassment, low wage, irregular work, excess responsibity and deprivation of modern equipment are very common hazards faced by agricultural farm women in their day-to-day work fields.

Table 3: Distribution of respondents on the basis of physical hazards and socio-economic class

\begin{tabular}{l|lllllll} 
Physical Hazards & \multicolumn{2}{l}{ lower Class } & \multicolumn{2}{l}{ Upper lower Class } & \multicolumn{2}{l}{ lower Middle Class } & Chi Square Value \\
\cline { 2 - 7 } & $\%$ & NO & $\%$ & NO & $\%$ & NO & $x^{2}=3.77$ \\
\multirow{2}{*}{ Body pain } & 47.27 & 52 & 31.82 & 35 & 7.27 & 8 & \\
\hline Fatigue & 44.55 & 49 & 33.64 & 37 & 5.45 & 6 \\
Headache & 34.55 & 38 & 18.18 & 20 & 4.55 & 5 \\
\hline Fever & 20 & 22 & 8.18 & 9 & 0.91 & 1 \\
Infection & 21.82 & 24 & 11.82 & 13 & 2.73 & 3
\end{tabular}

*Not Significant

Table 3 revealed that in all the agricultural activities, physical hazards such as body pain $(4.27 \%)$ and fatigue $(44.55 \%)$ were most common among the lower socio-economic class, whereas $34.55 \%, 20 \%$ and $21.82 \%$ of respondents had headache, fever and infection respectively and no association was found between their socio-economic classes in the relevance of physical health hazard. Ojha and Singh found in their study a significant difference $(p<0.0001)$ in physiological characteristics of male and female respondents.

Table 4: Distribution of respondents on the basis of mechanical hazards and socio-economic class

\begin{tabular}{|c|c|c|c|c|c|c|c|}
\hline \multirow[t]{2}{*}{ Mechanical hazards } & \multicolumn{2}{|c|}{ lower Class } & \multicolumn{2}{|c|}{ Upper lower Class } & \multicolumn{2}{|c|}{ lower Middle Class } & \multirow[t]{2}{*}{ Chi Square Value } \\
\hline & $\%$ & NO & $\%$ & NO & $\%$ & NO & \\
\hline Injuries with tools & 38.18 & 42 & 29.09 & 32 & 10 & 11 & $x^{2}=3.51$ \\
\hline Thermal hazards & 8.18 & 9 & 7.27 & 8 & 2.73 & 3 & \\
\hline Vibration hazards & 1.82 & 2 & 1.82 & 2 & 0.91 & 1 & \\
\hline Hearing loss & 2.73 & 3 & 0 & 0 & 0 & 0 & \\
\hline
\end{tabular}

*Not Significant

The majority of lower socio-economic class respondents $(38.18 \%)$ had mechanical hazards, i.e. injuries occurred due to farm tools and machinery, it was observed from table 4. Cold injuries, vibration injuries and hearing loss experience by $8.18 \%, 1.82 \%$ and $2.73 \%$ respectively lower socioeconomic class respondents and no association was found between their socio-economic classes in the relevance of mechanical hazard. 
Suravi, S. / Occupational health hazards of women in agriculture - a study on Bargarh district of Odisha

Table 5: Distribution of respondents on the basis of chemical hazards and socio-economic class

\begin{tabular}{|c|c|c|c|c|c|c|c|}
\hline \multirow[t]{2}{*}{ Chemical hazards } & \multicolumn{2}{|c|}{ lower Class } & \multicolumn{2}{|c|}{ Upper lower Class } & \multicolumn{2}{|c|}{ lower Middle Class } & \multirow[t]{2}{*}{ Chi Square Value } \\
\hline & $\%$ & $\mathrm{NO}$ & $\%$ & NO & $\%$ & NO & \\
\hline Rough skin & 27.27 & 30 & 9.09 & 10 & 2.73 & 3 & $\begin{array}{l}\chi^{2}=2.09 \\
*\end{array}$ \\
\hline Infection in eyes & 21.82 & 24 & 5.45 & 6 & 1.82 & 2 & \\
\hline Itching & 24.55 & 27 & 6.36 & 7 & 0.91 & 1 & \\
\hline
\end{tabular}

From table 5, it was shown that chemical hazards like skin problems affected $27.27 \%$ of the lower socio-economic class. Farmworkers who felt itching on their bodies followed with $24.55 \%$, and $21.82 \%$ of the lower socio-economic class farmworkers suffered from eye infection due to chemical hazards, and no association was found between their socio-economic classes in the relevance of chemical hazard.

Table 6: Distribution of respondents on the basis of environmental hazards and socio-economic class

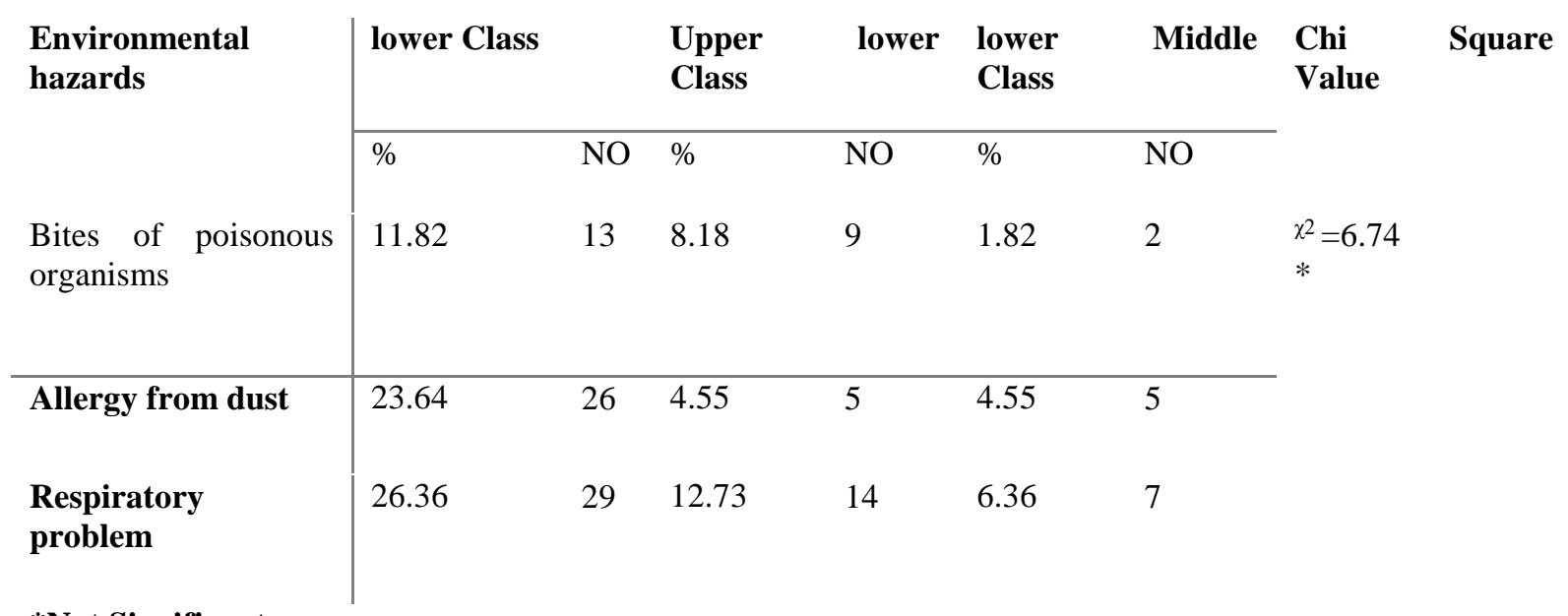

*Not Significant

Table 6 indicated that environmental hazards such as air-borne allergies (23.64\%), poisonous organism bites $(11.82 \%)$, and respiratory problems $(26.36 \%)$ were found common among the lower socio-economic class respondents. No association was found between their socio-economic classes in the relevance of environmental hazard.

Table 7: Distribution of respondents on the basis of psychological hazards and socio-economic class

\begin{tabular}{|c|c|c|c|c|c|c|c|}
\hline \multirow[t]{2}{*}{ Psychological Hazards } & \multicolumn{2}{|c|}{ lower Class } & \multicolumn{2}{|c|}{ Upper lower Class } & \multicolumn{2}{|c|}{ Middle lower Class } & \multirow[t]{2}{*}{ Chi Square Value } \\
\hline & $\%$ & $\mathrm{NO}$ & $\%$ & $\mathrm{NO}$ & $\%$ & NO & \\
\hline Harassment & 15.45 & 17 & 14.05 & 9 & 3.64 & 4 & $\begin{array}{l}\chi^{2}=11.27 \\
*\end{array}$ \\
\hline low Wage & 20.91 & 23 & 19.01 & 21 & 14.55 & 16 & \\
\hline Monoteneous work & 30.00 & 33 & 27.27 & 28 & 12.73 & 14 & \\
\hline
\end{tabular}


Suravi, S. I Occupational health hazards of women in agriculture - a study on Bargarh district of Odisha

\begin{tabular}{l|llllll}
\hline Irregular work & 19.09 & 21 & 17.36 & 9 & 3.64 & 4 \\
Excess Responsibity & 7.27 & 8 & 6.61 & 6 & 5.45 & 6 \\
\hline Deprive Moderen Equipment & 3.64 & 4 & 3.31 & 3 & 2.73 & 3 \\
Work Related Stress & 39.09 & 43 & 35.54 & 29 & 11.82 & 13 \\
$*$ Not Significant & & & & & &
\end{tabular}

Table 7 indicated that most farm agricultural workers had work-related stress. Of them, 39.09\% belonged to the lower socio-economic class, followed by $30 \%$ lower socio-economic class who had psychological hazards for monotonous work. Harassment, low wage, irregular work, excess responsibility and deprival of modern equipment are very common hazards faced by agricultural farm women in their day-to-day work fields, and no association was found between their socio-economic classes in the relevance of psychological health hazard.

Table 8: Distribution of respondents according to practices Adopted by the Farm women to overcome the Hazards

\begin{tabular}{llc}
\hline Body Pain & Massage Transformer oil at night & $75.45 \%$ \\
Fever & $\begin{array}{l}\text { Boiled water with Sephali Leaves (Nyctanthes arbor-tristis) } \\
\text { (twice a day) }\end{array}$ & $39.09 \%$ \\
\hline Infection & $\begin{array}{l}\text { Turmeric and Neem Leaves (Azadirachta indica) } \\
\text { Turmeric, amla (Phyllanthus-emblica), oil and Neem Leave }\end{array}$ & $85.45 \%$ \\
\hline $\begin{array}{l}\text { Infection in eyes } \\
\text { Itching }\end{array}$ & Saliva & $32.72 \%$ \\
\hline $\begin{array}{l}\text { Bites of } \\
\text { organisms } \\
\text { Injuries }\end{array}$ & Cow Dung applied to the itching area & $46.36 \%$ \\
\hline
\end{tabular}

Table 8 revealed that $75.45 \%$ of farm women massage transformer oil at night for body pain. They drank boiled water with sephali leaves twice a day for relief from fever, i.e. 39.09\%. Turmeric paste and neem leaves are very common in this locality and are applied when there is an occurrence of infection (85.45\%). $76.36 \%$ of respondents used turmeric, amla, oil, and neem leaves to prevent rough skin. They used saliva when they feel an infection or foreign body in the eyes (32.72\%). $46.36 \%$ of respondents applied cow dung on itching area. If they feel the bite of any poisonous organism, then they apply Cynodon Dactylon (white Duba) roots paste. It was interesting to note that majority of respondents $(92.72 \%)$ applied Tridax paste in injuries.

\section{Preventive measure}

- Analysis of working conditions by regular farm visits.

- Assessing and monitoring of work-related health hazards.

- Surveillance of health through medical check-ups.

- Drawing up proposals to improve working conditions.

- Adjusting work tasks according to the employee's capabilities. 


\section{Suravi, S. / Occupational health hazards of women in agriculture - a study on Bargarh district of Odisha}

\section{Conclusion}

The present study is based on 110 samples of 3 villages across the different agro/ecosystems with a majority of low and some middle-income holders. Interestingly the women farmers are generally knowledgeable with some educational background. Relatively, majority of young age groups (20-40) years old represent $68 \%$. A few different types of hazards were mentioned, including body pain, fatigue, allergies and mechanical injury. Important findings indicate that the farmers are not aware of preventive measures against the hazards, and there is no association linked with the agricultural hazards and to reduce the same attached to this.

\section{Acknowledgements}

I would like to thank Dr. Chandrashree Lenka, H.O.D, P.G. Department of Home Science, Sambalpur University, for her guidance in preparing the paper.

\section{References}

[Davey, S., Maheshwari, C., Raghav, S., Singh, J., Singh, N., \& Davey, A., 2017. Impact of occupational health hazards prevention messages on perceptions among rural clients in India: The outcomes of a panel study. International Journal of Health System and Disaster Management, 5(1), 11.

Jyoti V. Vastrad, Rajashri, K., \& Shameembanu A. B., 2014, Occupational Health Hazards of Agricultural Laborers, Journal of Human Ecology, 48(3), 423-429.

Meenakshi, J. R., \& Panneer, S., 2020, Occupational Health of Agricultural Women Workers in India. Indian journal of community medicine: official publication of Indian Association of Preventive \& Social Medicine, 45(4), 546-549.

Nayak., J., Singh S. P., and Moharana., G., Occupational health hazard of farm women. Directorate of research on women in agriculture (Indian council of agricultural research) Bhubaneswar 751 003, Odisha, technical bulletin no. 24

Ojha., P and Singh., A., 2018, Assessment of occupational health hazards among farm workers involved in agricultural activities. Journal of pharmacognosy and phytochemistry. 1369-1372.

Pandey., S., 2014, An epidemiological study of mechanical health hazards amongst agricultural workers in rural India. International journal of occupational safety and health, 4 (2), 9-23 